\title{
ANALISIS LIKUIDITAS SAHAM MENGGUNAKAN REGRESI DATA PANEL
}

\author{
Indah Putra' ${ }^{1)}$, Irdha Yusra ${ }^{2)}$ \\ Sekolah Tinggi Ilmu Ekonomi KBP \\ Indahputra402@gmail.com \\ irdhayusra@akbpstie.ac.id
}

\begin{abstract}
Liquidity very important for investors when they decided stock which that is pulled to invest. The higher the number of share transactions in the capital market in a particular period the liquid the shares. The purpose of this study is to find how big the impact of profitability and probability of profit losers to stock liquidity at companies registered at the indonesian stock exchange the period 2013 - 2017. Technique the sample collection uses the method purposive sampling and based on the criteria which had been determined obtained samples from 16 company. Data from the financial reports obtained from official website of IDX. The analytical method used is regression analysis of panel data with the help of application E-Views 8. After he did chow-test it is decided to choose in a fixed effect method. Stock Liquidity at listed companies on IDX during the period research only influenced positively and significant by gross profit margin, but the probability profit losers had an impact negative and not significant.
\end{abstract}

Keywords : Stock Liquidity, Bid-ask spread, Gross Profit Margin, probability profit losers .

\section{PENDAHULUAN}

Perusahaan dalam menjalankan aktivitasnya selalu membutuhkan dana, baik untuk kegiatan operasional maupun perluasan usaha. Dana ini dapat diperoleh dari modal pemilik dan dari kreditor. Akan tetapi, perusahaan yang besar biasanya tidak cukup jika harus mengandalkan modal dari pemilik dan kreditor. Untuk mengatasi hal tersebut, perusahaan dapat menarik dana dari masyarakat yaitu melalui peredaran saham. Saham yang diedarkan perusahaan diperdagangkan di bursa efek atau pasar modal.

Menurut Mulyaningsih (2013), jumlah saham beredar yang cukup banyak memungkinkan saham tersebut ditransaksikan oleh investor. Investor cenderung lebih memilih perusahaan yang memiliki saham yang likuid karena kemungkinan memperoleh laba yang cukup besar di masa yang akan datang dan investor ikut mendapatkan keuntungan melalui pembagian deviden. Selain jumlah saham yang beredar, investor mendasarkan keputusannya pada berbagai informasi yang dimilikinya, baik informasi yang tersedia di publik maupun informasi pribadi.

Dampak signifikan pada keputusan tentang daya tarik investasi suatu saham tidak hanya dihasilkan oleh return yang diharapkan, stabilitas perusahaan, keterbukaan terhadap investor, namun juga oleh likuiditas. Investor lebih memilih saham yang likuid dan dalam kasus persediaan yang tidak likuid mereka membutuhkan bonus tertentu sehingga membuat likuiditas menjadi faktor risiko (Norvaišienė and Stankevičienė 2014).

Teori keagenan mendeskripsikan hubungan antara pemegang saham sebagai principal dan manajemen sebagai agen. Indahningrum \& Handayani (2009), mendefinisikan agency cost sebagai jumlah dari biaya yang dikeluarkan prinsipal untuk melakukan pengawasan terhadap agen. Dalam rangka menjamin manajer mengambil 
keputusan yang optimal sangat mustahil bagi perusahaan memiliki zero agency cost karena adanya perbedaan kepentingan yang besar.

Likuiditas merupakan kemampuan suatu aktiva atau instrumen untuk berubah bentuk menjadi kas atau setara kas. Dengan kata lain, jika investor ingin menjual saham, maka ada investor lain yang siap untuk membeli dan jika investor ingin membeli saham, maka ada investor yang bersedia untuk menjual sahamnya. Tingkat likuiditas suatu saham didorong oleh transaksi-transaksi yang dilakukan terhadap saham. Semakin sering suatu saham ditransaksikan menunjukkan tingkat mobilitas yang tinggi dan semakin mudah saham tersebut diperdagangkan dan menunjukkan semakin likuid saham tersebut (Wira 2012).

Likuiditas saham merupakan ukuran jumlah transaksi saham di pasar modal dalam periode tertentu. Semakin tinggi frekuensi transaksi maka semakin tinggi likuiditas saham, ini berarti saham tersebut semakin diminati oleh para investor dan hal tersebut akan tingkat harga saham yang bersangkutan (Magdalena \& Choery, 2008; Imtihani, 2017).

Norvaišienė \& Stankevičienė (2014), mengusulkan bahwa likuiditas dapat diperlakukan sebagai frekuensi perdagangan saham di pasar. Generalisasi pertimbangan ini menunjukkan bahwa likuiditas saham adalah kemampuan untuk membeli atau menjual saham dengan cepat dan dalam volume tinggi tanpa ada dampak signifikan pada harga dan tanpa menimbulkan biaya transaksi yang tinggi.

Profitabilitas adalah rasio dari kemampuan manajemen berdasarkan perolehan pengembalian yang diperoleh dari penjualan dan investasi. Rasio profitabilitas terbagi dari : basic earning power, profit margin, return on equity dan return on assets (Sartono 2001; Kasmir 2008).

Menurut Weston \& Brigham (1990) teori probabilitas merupakan teori yang mendefinisikan suatu kemungkinan yang mungkin terjadi baik itu laba ataupun rugi dalam suatu perusahaan. Maksud dari teori ini adalah memperkirakan probabilitas untuk setiap hasil yang mungkin terjadi. Misalnya, peramal cuaca akan mengatakan, "Hari ini kemungkinan 40\% akan turun hujan dan 60\% tidak. " Jika kita membuat daftar setiap peristiwa yang mungkin terjadi dan memberikan probabilitas kepada masing-masing peristiwa maka daftar itu disebut distribusi probabilitas.

Beberapa penelitian terdahulu telah melakukan kajian secara empiris mengenai dampak profitabilitas dan probabilitas laba rugi terhadap likuiditas saham. Norvaišienė \& Stankevičienè (2014) menemukan bahwa likuiditas saham dipengaruhi secara positif oleh laba atas aset dan probabilitas laba rugi. Temuan ini berbeda dengan penelitian Mulyaningsih (2013), yang menemukan bahwa profitabilitas tidak berpengaruh terhadap likuiditas saham.

Mengingat adanya berbagai macam temuan-temuan empiris tentang dampak profitabilitas dan probabilitas laba rugi terhadap likuiditas saham. Maka penelitian ini menjadi menarik untuk dilakukan kajian secara mendalam, terutama untuk menjawab permasalahan tentang seberapa besarnya dampak profitabilitas dan probabilitas laba rugi terhadap likuiditas saham pada perusahaan yang terdaftar di Bursa Efek Indonesia. Dengan adanya permasalahan ini, penelitian ini dapat memberikan bukti secara empiris bahwa profitabilitas dan probabilitas laba rugi berpengaruh signifikan terhadap likuiditas saham.

Cek pengembangan hipotesis di BAB II, copypaste/pindahkan dibagian ini sebelum hipotesis dirumuskan. Karena dasar pengembangan hipotesis belum rinci. 


\section{METODE PENELITIAN}

\section{Data dan Sampel}

Penelitian ini dilakukan pada perusahaan yang terdaftar di Bursa Efek Indonesia. Alasan pemilihan obyek ini ialah agar dalam pemilihan sampel tidak terdapat kendala kekurangan data sesuai variabel yang akan di uji, dan titik informasi yang pasti mengenai industri yang telah go publik.

Dalam penelitian ini Annual Report dan Summary digunakan sebagai sumber data utama. Jenis data yang didapatkan dari Annual Report dan Summary berupa data kuantitatif. Data kuantitatif yang digunakan seperti laporan laba rugi, laporan ekuitas, laporan neraca dan catatan laporan akhir periode Desember 2013 sampai Desember 2017. Teknik pengumpulan data yang digunakan adalah dokumentasi.

Populasi pada penelitian ini yaitu perusahaan yang terdaftar pada Bursa Efek Indonesia di akhir periode observasi, yaitu tahun 2017 sebanyak 539 Perusahaan. Metode pemilahan sampel pada pengamatan ini dilakukan dengan metode purposive sampling yaitu metode penarikan sampel dengan penilaian yang berdasarkan kriteria sesuai dengan objek maupun subjek yang untuk diamati(Sugiyono, 2017). Kriteria untuk pengambilan sampel pada pengamatan ini yaitu :

1. Perusahaan yang terdaftar di Bursa Efek Indonesia pada akhir periode obsevasi, yaitu Tahun 2017.

2. Perusahaan yang terdaftar secara berturut-turut pada Bursa Efek Indonesia selama periode observasi (2013 - 2017).

3. Perusahaan yang menerbitkan laporan keuangan yang lengkap selama periode observasi.

4. Perusahaan yang memiliki data keuangan sesuai dengan variabel yang akan diuji. Yaitu LS, ROA, ROE, ROI, GPM, NPM, PROB.

Berdasarkan kriteria-kriteria tersebut, maka diperoleh sampel sesuai dengan Tabel berikut :

Tabel 1

\section{Daftar Perusahaan Sampel}

\begin{tabular}{clc}
\hline No. & \multicolumn{1}{c}{ EMITEN } & KODE \\
\hline $\mathbf{1}$ & Sampoerna Argo Tbk & SGRO \\
$\mathbf{2}$ & SMART Tbk & SMAR \\
$\mathbf{3}$ & Tunas Baru Lampung Tbk & TBLA \\
$\mathbf{4}$ & Holcim Indonesia Tbk & SMCB \\
$\mathbf{5}$ & Argha Karya Prima Industry Tbk & AKPI \\
$\mathbf{6}$ & Trias Sentosa Tbk & TRST \\
$\mathbf{7}$ & Yanaprima Hastapersada Tbk & YPAS \\
$\mathbf{8}$ & Japfa Comfeed Tbk & JPFA \\
$\mathbf{9}$ & Alkindo Naratama Tbk & ALDO \\
$\mathbf{1 0}$ & Indah Kiat Pulp and Paper Tbk & INKP \\
$\mathbf{1 1}$ & Astra Indonesia Tbk & ASII \\
$\mathbf{1 2}$ & Indo Kordsa Tbk & BRAM \\
$\mathbf{1 3}$ & Indomobil Sukses Internasional & IMAS
\end{tabular}


14 Multistrada Arah Sarana Tbk

MASA

15 Eratex Djaja Tbk

ERTX

16 Voksel Elektic Tbk.

VOKS

\section{Definisi Operasional Variabel}

Dalam penelitian ini terdiri dari dua macam variabel yaitu variabel independent (variabel bebas) dan dependent (variabel terikat) (Ghozali 2012). Variabel independent yaitu Profitabilitas $\left(\mathrm{X}_{1}\right)$, Probabilitas Laba-Rugi $\left(\mathrm{X}_{2}\right)$. Variabel dependent yaitu Leverage (Y). Selanjutnya dapat diuraikan definisi operasionalnya dari pengamatan ini sebagai berikut :

Tabel 2

Definisi Operasional Variabel

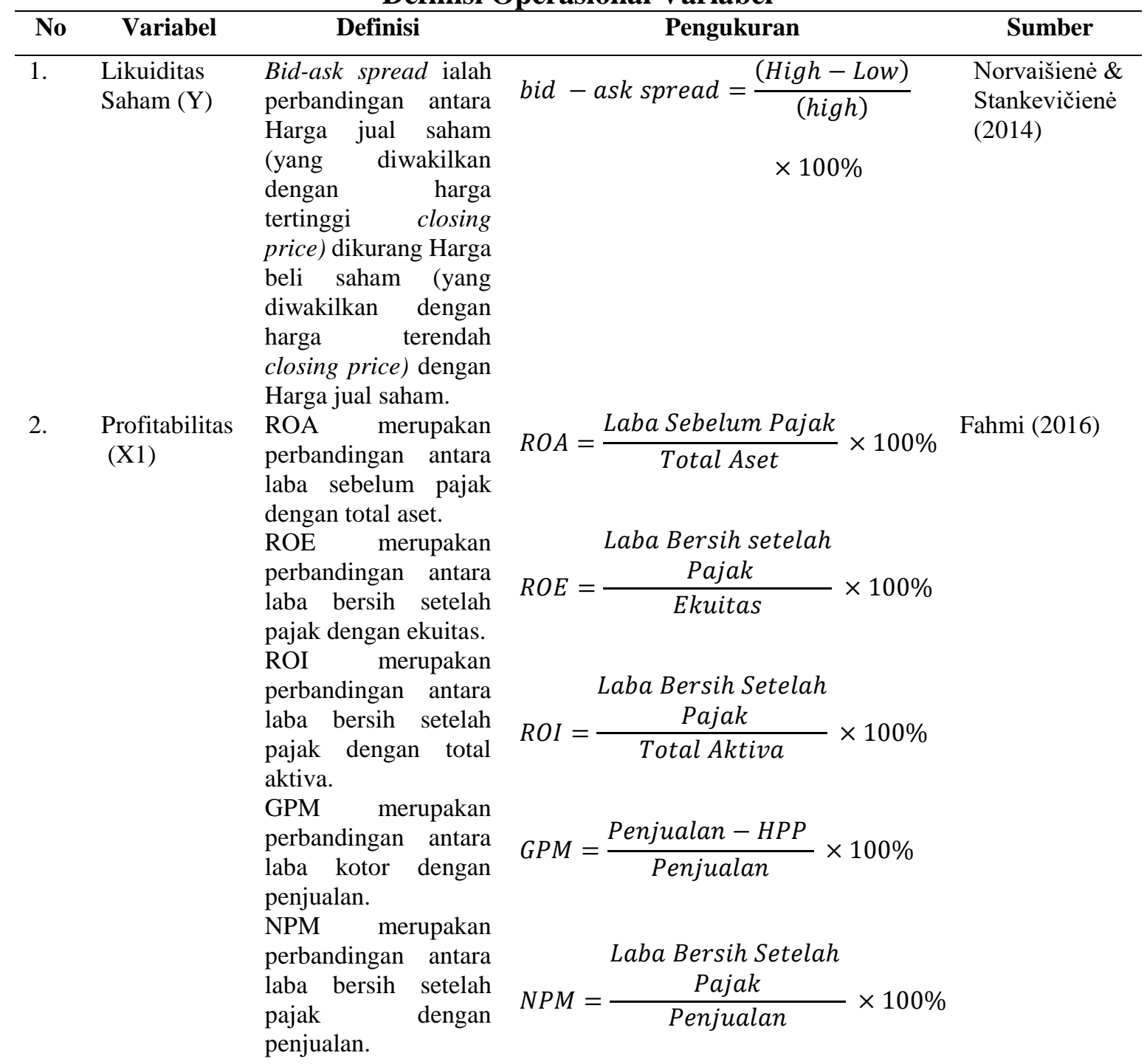




\begin{tabular}{|c|c|c|c|c|}
\hline 3. & $\begin{array}{l}\text { Probabilitas } \\
\text { Laba-Rugi } \\
\text { (X2) }\end{array}$ & 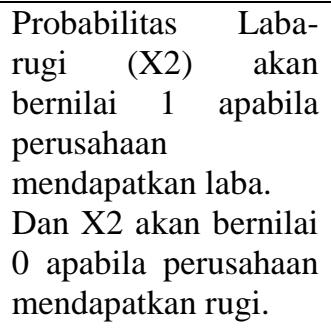 & $\begin{aligned} \mathrm{X} 2= & 1, \text { Jika perusahaan mendapatkan } \\
& \text { laba. } \\
\mathrm{X} 2= & 0, \text { Jika perusahaan mendapatkan } \\
& \text { rugi. }\end{aligned}$ & $\begin{array}{l}\text { Weston \& } \\
\text { Brigham (1990) }\end{array}$ \\
\hline
\end{tabular}

\section{Teknik Analisis Data}

Dalam penelitian ini dilakukan pengujian hipotesis yang bertujuan menguji pengaruh profitbilitas dan probabilitas laba-rugi terhadap likuiditas saham. Dalam penelitian ini data yang digunakan yaitu data panel, yang merupakan gabungan antara data time series dan cross section. Data sampel sebanyak 16 perusahaan diambil dari data unit cross section dan data time series periode 2013-2017.

Analisis statistik deskriptif merupakan metode analisis yang digunakan dalam penelitian ini dan menggunakan Program Eviews (Winarno 2015) untuk analisi regresi data panel. Persamaan regresi data panel yang digunakan dalam penelitian ini adalah :

$$
\mathrm{LS}_{\text {it }}=\alpha+\beta_{1} \mathrm{PROF}_{\mathrm{it}}+\beta_{2} \mathrm{PROB}_{\mathrm{LR}}+\mathrm{e}
$$

Dimana LSit merupakan Likuiditas Saham Perusahaan pada waktu t, $\alpha$ merupakan konstanta (intercept), $\beta 1, \beta 2$ merupakan Koefisien Regresi, PROFit merupakan Profitabilitas (Proksi Gross Profit Margin) Perusahaan pada waktu t, PROB LRit merupakan Probabilitas Laba-Rugi Perusahaan pada waktu t dan e merupakan Standar error.

Pendekatan yang dilakukan dalam analisis regresi data panel yaitu common effect model (CEM), Fixed effect Model (FEM), random effect model (REM) (Yusra, Hadya and Egawati, 2017; Ruri, 2007). Ada dua tahapan yang dilakukan untuk menentukan model yang terbaik digunakan antara model tersebut yaitu: Uji Chow, untuk menentukan model mana yang terbaik antara common effect model (CEM) dengan Fixed effect Model (FEM). Uji Hausman, dilakukan untuk menentukan model mana yang terbaik digunakan antara Fixed effect Model (FEM) dengan random effect model (REM).

\section{HASIL DAN PEMBAHASAN Analisis Statistik Deskriptif}

Uji statistik deskriptif bertujuan untuk memberikan gambaran umum obyek penelitian. Perhitungan statistik deskriptif dalam penelitian ini meliputi nilai minimum, maksimum, rata-rata, maupun standar deviasi dari masing-masing variabel. Variabel dependen pada penelitian ini adalah likuiditas saham sedangkan variabel independen penelitian ini adalah profitabilitas dan probabilitas laba-rugi. Distribusi statistik untuk masing-masing variabel dalam penelitian ini terdapat pada Tabel 3 dibawah ini:

Tabel 3

Deskripsi Statistik

\begin{tabular}{lcccc}
\hline \multicolumn{1}{c}{ Variabel } & Minimum & Maksimum & Mean & Standar Deviasi \\
\hline Likuiditas Saham (LS) & 0.000000 & 89.31 & 46.3946 & 19.0286 \\
Profitabilitas (GPM) & 4.600000 & 34.64 & 16.3181 & 6.303254 \\
Probabilitas (PROB) & 0.000000 & 1 & 0.8125 & 0.392775 \\
\hline
\end{tabular}


Berdasarkan tabel 3 bisa dijelaskan bahwa penelitian ini memiliki jumlah data sampel sebanyak 80 observasi yang mana di variabel Profitabilitas nilai minimum data adalah senilai 4,6 yang terdapat di perusahaan Eratex Djaja Tbk pada tahun 2017. Serta nilai maksimum data senilai 34,64 yang terdapat di perusahaan Holcim Indonesia Tbk pada tahun 2013. Serta rata-rata (Mean) data Profitabilitas (yang diproksi dengan GPM) sebesar 16,32 yang artinya kemampuan perusahaan menghasilkan laba kotor lebih besar dibandingkan dengan penjualan. Nilai standar deviasi Profitabilitas (yang diproksi dengan GPM) sebesar 6,3 hal ini menunjukkan penyebaran data yang lebih kecil karena nilainya lebih rendah dari nilai rata-rata (mean).

Selanjutnya di variabel Probabilitas Laba Rugi dengan jumlah data sampel yang sama, nilai minimum data senilai 0 . Serta nilai maksimum data senilai 1. Serta nilai ratarata (Mean) data Probabilitas Laba Rugi sebesar 0,81 yang artinya kemungkinan kemampuan perusahaan menghasilkan laba lebih besar dibandingkan dengan kerugian perusahaan. Nilai standar deviasi Probabilitas Laba Rugi sebesar 0,39 hal ini menunjukkan penyebaran data yang lebih kecil karena nilainya lebih rendah dari nilai rata-rata (mean).

Dan di variabel Likuiditas Saham dengan jumlah data sampel yang sama, nilai minimum data senilai 0 yang terdapat di perusahaan Alkindo Naratama Tbk pada tahun 2017. Serta nilai maksimum data senilai 89,31 yang terdapat di perusahaan Eratex Djaja Tbk pada tahun 2016. Serta nilai rata-rata (Mean) data Likuiditas Saham yang berarti tingkat Harga jual saham (yang diwakilkan dengan harga tertinggi closing price) dikurang Harga beli saham (yang diwakilkan dengan harga terendah closing price) dibandingkan Harga jual saham (harga tertinggi) sebesar 46,39. Nilai standar deviasi Likuiditas Saham sebesar 19,03 hal ini menunjukkan penyebaran data yang lebih kecil karena nilainya lebih rendah dari nilai rata-rata (mean).

\section{Pemilihan Regresi Data Panel}

Dalam data panel untuk pemilihan model yang terbaik dilakukan tahap analisis dengan cara melakukan estimasi model Common Effect (CEM), Fixed Effect (FEM), dan Random Effect (REM). Hasil statistik yang diperoleh dalam pengestimasian model CEM, FEM, dan REM adalah sebagai berikut:

Tabel 4

Tabel Hasil Estimasi CEM, FEM, REM

\begin{tabular}{ccccccc}
\hline \multirow{2}{*}{ Variabel } & \multicolumn{2}{c}{ Common Effect } & \multicolumn{2}{c}{ Fixed Effect } & \multicolumn{2}{c}{ Random Effect } \\
\cline { 2 - 7 } & t-statistik & prob & t-statistik & prob & t-statistik & \multicolumn{1}{c}{ prob } \\
\hline GPM & 0.068201 & 0.9458 & 2.083594 & 0.0413 & 1.276297 & 0.2057 \\
PROB & 0.082316 & 0.9346 & -1.063581 & 0.2916 & -0.575296 & 0.5668 \\
\hline
\end{tabular}

Tabel di atas menunjukkan bahwa nilai $\mathrm{t}$ statistik dan probabilitas untuk masingmasing model sebagai dasar pemilihan model terbaik dalam regresi data panel. Hasil estimasi menjelaskan bahwa masing-masing model memiliki nilai signifikansi yang berbeda-beda. Oleh sebab itu, untuk menemukan model mana yang terbaik maka dilakukan analisis lebih lanjut dengan menggunakan Uji Chow dan Hausman Test. 
Tabel 5

Uji Chow

\begin{tabular}{lccc}
\hline Effects Test & Statistic & d.f. & Prob. \\
\hline Cross-section F & 4.28938 & $(15,62)$ & 0 \\
Cross-section Chi-square & 56.94783 & 15 & 0
\end{tabular}

Uji chow bertujuan untuk menentukan model yang lebih baik digunakan antara model Common Effect dan Fixed Effect. Berdasarkan tabel di atas diperoleh nilai prob pada Cross-section Chi-square lebih kecil dari alpha $(\alpha)(0<0.05)$, maka H0 ditolak. Artinya model Fixed Effect lebih baik digunakan dari model Common Effect.

Tabel 6

Uji Hausman

\begin{tabular}{lccc}
\hline Test Summary & Chi-Sq. Statistic & Chi-Sq. d.f. & Prob. \\
\hline Cross-section random & 3.0507 & 2 & 0.2175 \\
\hline
\end{tabular}

Uji Hausman bertujuan untuk menentukan model yang lebih baik antara model Fixed Effect dan model Random Effect. Tabel 6 menunjukkan bahwa nilai prob pada Cross-section random lebih kecil dari alpha $(\alpha)(0.2175<0.05)$, sehingga H0 ditolak. Dengan demikian, disimpulkan bahwa model yang cocok digunakan dalam regresi data panel adalah Fixed Effect Model (FEM).

\section{Uji Asumsi Klasik}

Pengujian asumsi klasik yang akan dilakukan ialah uji normalitas. Uji normalitas dipakai untuk menguji apakah didalam sebuah bentuk regresi, variabel Likuiditas Saham dan variabel Profitabilitas serta Probabilitas Saham mempunyai distribusi normal atau tidak. Perolehan uji normalitas data sebagai berikut :

Tabel 7

Uji Normalitas

\begin{tabular}{cc}
\hline Jarque-Bera & Probability \\
\hline 2.064768 & 0.356157 \\
\hline
\end{tabular}

Nilai Prob.JB hitung sebanyak $0.356157>0.05$ sehingga dapat disimpulkan bahwa residual telah terdistribusi secara normal yang artinya asumsi klasik tentang kenormalan data telah terpenuhi.

\section{Analisis Regresi Data Panel}

Penelitian ini dilakukan untuk melihat pengaruh variabel independen terhadap variabel dependen. Analisis regresi data panel digunakan untuk melihat apakah hipotesis yang telah dibuat akan diterima atau ditolak. Tingkat signifikansi yang digunakan adalah 5\%. Model statistik yang diestimasi merupakan model yang terbaik dan terbebas dari penyimpangan asumsi klasik (Yusra, Hadya, \& Egawati, 2017). Diantara model regresi data panel yang diestimasi dalam penelitian ini,maka diperoleh bahwa CEM/FEM/REM merupakan model terbaik. Hasil pengujian di penelitian ini bisa diketahui pada tabel berikut : 
Tabel 8

Hasil Uji Regresi Data Panel

\begin{tabular}{crrrr}
\hline Variable & Coefficient & Std. Error & t-Statistic & Prob. \\
\hline C & 32.21992 & 8.805023 & 3.659266 & 0.0005 \\
GPM & 1.205644 & 0.578637 & 2.083594 & 0.0413 \\
PROB & -6.768186 & 6.363583 & -1.06358 & 0.2916 \\
\hline
\end{tabular}
berikut :

Berdasarkan tabel di atas, maka diperoleh persamaan regresi data panel sebagai

$$
L S=32.22+1.21 \text { PROF }-6.77 \text { PROB LR }
$$

Pada model persamaan regresi diatas, dapat diinterpretasikan bahwa konstanta bernilai 32.21992 ini menjelaskan bahwa jika diasumsikan variabel X (Profitabilitas dan Probabilitas Laba Rugi) bernilai 0 (tidak ada), maka Likuiditas Saham bernilai konsta sebesar 32.21992.

Selanjutnya koefisien Profitabilitas (GPM) sebesar 1.205644 artinya setiap peningkatan variabel Profitabilitas (yang diproksi dengan GPM) sebanyak 1 satuan berarti akan meningkatkan variabel Likuiditas Saham sebanyak 1.205644 serta beranggapan variabel lain dalam bentuk konstan.

Dan koefisien Probabilitas LR (PROB) sebesar -6.768186 artinya setiap peningkatan variabel Probabilitas Laba Rugi sebanyak 1 satuan berarti akan menurunkan variabel Likuiditas Saham sebanyak -6.768186 serta beranggapan variabel lain dalam bentuk konstan.

\section{Hasil Pengujian Hipotesis}

Pada penelitian ini menggunakan uji t. Uji t statistik menunjukkan seberapa besar pengaruh suatu variabel indepnden terhadap variabel dependen, dilaksanakan untuk memeriksa lebih lanjut apakah variabel Profitabilitas (yang diproksi dengan GPM) dan Probabilitas Laba Rugi tersebut signifikan atau tidak terhadap variabel Likuiditas Saham, Sejauh mana pengaruh variabel penjelas sebagai individu dalam menerangkan varianvarian terikat.

Tabel 9

Hasil Pengujian Hipotesis

\begin{tabular}{rcccccc}
\hline Variabel & Koefisien & t-statistik & t-tabel & prob & alpha & Kesimpulan \\
\hline Profitabilitas (GPM) & 1.205644 & 2.083594 & 1.99006 & 0.0413 & 0.05 & H1 Diterima \\
Probabilitas (PROB) & -6.768186 & -1.063581 & 1.99006 & 0.2916 & 0.05 & H2 Ditolak \\
\hline
\end{tabular}

Berdasarkan tabel diatas diperoleh nilai t hitung untuk variabel Profitabilitas (yang diproksi dengan GPM) senilai $2.083594>\mathrm{t}$ tabel 1.99006 serta prob 0.0413. Nilai prob. Profitabilitas (yang diproksi dengan GPM) senilai $0.0413<0,05$ berarti H1 diterima 
artinya ada pengaruh yang signifikan antara variabel Profitabilitas (yang diproksi dengan GPM) terhadap Likuiditas Saham.

Dan nilai t hitung untuk variabel Probabilitas Laba Rugi senilai $-1.063581<\mathrm{t}$ tabel 1.99006 serta prob 0.2916. Nilai prob. Probabilitas Laba Rugi senilai $0.2916>0,05$ berarti H2 ditolak artinya tidak ada pengaruh yang signifikan antara variabel Probabilitas Laba Rugi terhadap Likuiditas Saham.

\section{Pembahasan}

Hasil analisis data untuk hipotesis pertama yang dikemukakan dalam penelitian ini yaitu bahwa diduga Profitabilitas (yang diproksi dengan GPM) berpengaruh positif dan signifikan terhadap Likuiditas Saham. Berdasarkan hasil uji nilai t hitung untuk variabel Profitabilitas (yang diproksi dengan GPM) membuktikan bahwa H1 diterima artinya ada pengaruh yang signifikan antara Profitabilitas (yang diproksi dengan GPM) terhadap Likuiditas Saham. Hal ini menjelaskan bahwa Gross Profit Margin berpengaruh pada Likuiditas Saham dimana jika Gross Profit Margin meningkat berarti juga akan meningkatkan Likuiditas Saham. Semakin besar rasio laba kotor terhadap penjualan berarti pengelolaan suatu perusahaan semakin baik yang nantinya akan mempengaruhi keputusan investor dan akan berdampak pada likuiditas saham suatu perusahaan. Hasil ini juga diperkuat dengan penelitian terdahulu yang mana diteliti oleh (Norvaišienè and Stankevičienė 2014) yang menjelaskan bahwa hubungan likuiditas saham dengan faktor tingkat perusahaan membuktikan bahwa likuiditas saham dipengaruhi secara positif oleh ukuran perusahaan dan laba atas aset (Profitabilitas).

Hipotesis kedua menyatakan bahwa Probabilitas Laba Rugi berpengaruh signifikan terhadap Likiditas Saham. Berdasarkan hasil uji nilai t hitung untuk variabel Probabilitas Laba Rugi membuktikan bahwa $\mathrm{H} 2$ ditolak artinya tidak ada pengaruh yang signifikan antara variabel Probabilitas Laba Rugi terhadap Likuiditas Saham. Tidak berpengaruhnya Probabilitas Laba Rugi kemungkinan disebabkan oleh banyaknya data yang tereleminasi pada waktu penyeleksian data yang telah dilakukan karna banyaknya data yang terindikasi outliers sebanyak 88 perusahaan. Idealnya bahwa tinggi rendahnya tingkat Likuiditas Saham hanya ditentukan oleh harga jual dan harga beli saham. Semakin kecil selisih antara harga jual dan harga beli akan semakin likuid suatu saham, sebaliknya jika selisih antara harga jual dan harga beli besar maka semakin tidak likuid suatu saham. Namun, hasil temuan menunjukkan hal yang bertolak belakang dengan yang seharusnya. Hal ini berarti tinggi rendahnya tingkat Likuiditas Saham tidak ditentukan oleh Probabilitas Laba Rugi.

\section{SIMPULAN}

Dari hasil analisis data yang telah dilakukan, kesimpulan yang dapat ditarik dari penelitian ini adalah profitabilitas (yang diproksi dengan GPM) berpengaruh positif dan signifikan terhadap Likuiditas Saham pada perusahaan yang terdaftar di Bursa Efek Indonesia Periode 2013-2017. Artinya, perusahaan yang memiliki tingkat Gross Profit Margin yang tinggi maka Likuiditas Saham juga akan cenderung tinggi. Sedangkan probabilitas Laba Rugi tidak berpengaruh signifikan terhadap Likuiditas Saham pada perusahaan yang terdaftar di Bursa Efek Indonesia Periode 2013-2017. Artinya, perusahaan yang memiliki tingkat Probabilitas Laba Rugi yang tinggi maka Likuiditas Saham juga akan cenderung rendah.

Ada beberapa keterbatasan yang ditemukan dalam penelitian ini, diantaranya adalah jumlah periode observasi yang digunakan relatif sedikit. Untuk peneliti 
selanjutnya dapat menambah jumlah periode observasi yang lebih banyak, misalnya 10 tahun terakhir agar hasilnya lebih akurat. Keterbatasan lain adalah faktor-faktor yang digunakan hanya terbatas pada dua faktor saja, yaitu profitabilitas, dan probabilitas labarugi. Dengan keterbatasan tersebut, penelitian yang dilakukan belum memberikan gambaran yang maksimal. Berdasarkan keterbatasan tersebut, rekomendasi untuk penelitian berikutnya adalah dapat menambah atau mengembangkan variabel penelitian lain. Seperti leverage, likuiditas aset atau yang lainnya.

\section{UCAPAN TERIMAKASIH}

Peneliti mengucapkan terima kasih kepada pihak-pihak yang telah memberikan dukungan dan dorongan dalam melakukan penelitian ini. Penghargaan dan ucapan terima kasih kepada Bursa Efek Indonesia yang telah menyediakan akses kedalam laporan keuangan tahunan (Annual Report dan Summary) perusahaan yang terdaftar di BEI. Sehingga memudahkan peneliti untuk mengumpulkan data sesuai dengan data yang peneliti butuhkan.

Terima kasih juga penulis ucapkan kepada Ketua Sekolah Tinggi Ilmu "KBP", Ketua Program Studi Manajemen, Dosen Pembimbing serta dosen dan karyawan Sekolah Tinggi Ilmu "KBP" yang telah memberikan support, mengizinkan kepada penulis untuk melakukan penelitian dan penulisan jurnal ini.

\section{DAFTAR PUSTAKA}

Fahmi, Irham. 2016. Pengantar Manajemen Keuangan. Bandung: Alfabeta.

Ghozali. 2012. "Pengaruh Drop Box Dan E-Filling Terhadap Kepatuhan Penyampaian SPT Tahunan PPh.”: 44-55.

Imtihani, Zujhrifa. 2017. "Implikasi Volume Perdagangan, Bid- Ask Spead, Return Pasar, Dan Volalitas Harga Saham Terhadap Likuiditas Saham (Studi Pada Perusahaan Makanan Dan Minuman Yang Terdaftar Di Bursa Efek Indonesia Periode 20132015)." Universitas Lampung.

Indahningrum, Rizka putri, and Ratih Handayani. 2009. "Kebijakan Hutang Perusahaan." 11(3): 189-207.

Magdalena, Maria, and M Choery. 2008. "Analisis Likuiditas Saham Sebelum Dan Sesudah Stock Split Di Indonesia Pada Tahun 2008." STIE Nusa Megarkencana Yogyakarta: $29-39$.

Mulyaningsih, Ayu. 2013. “Analisis Pengaruh Jumlah Saham Beredar, Arus Kas, Dan Rasio Profitabilitas Terhadap Likuiditas Saham Pada Perusahaan Otomotif Yang Terdaftar Di Bursa Efek Indonesia." Universitas Gunadarma 5: 8-9.

Norvaišienè, Rasa, and Jurgita Stankevičienè. 2014. "Impact of Companies' Internal Factors on Stock Liquidity in Baltic Markets." Procedia - Social and Behavioral Sciences 156(April): 543-47. http://linkinghub.elsevier.com/retrieve/pii/S1877042814060571.

Ruri, Setiani. 2007. "Pengaruh Keputusan Investasi,keputusan Pendanaan Dan Tingkat Suku Bunga Terhadap Nilai Prusahaan.” : 1-10.

Sartono. 2001. Manajemen Keuangan Teori Dan Aplikasi. Yogyakarta: BPEFYogyakarta.

Sugiyono. 2017. Metode Penelitian Bisnis. Bandung: Alfabeta.

Weston, J. Fred, and Eugene F. Brigham. 1990. Manajemen Keuangan. Sembilan. Jakarta: Erlangga.

Winarno, wing wahyu. 2015. Analisis Ekonometrika Dan Statistika Dengan Eviews. 4th 
ed. Yogyakarta: Upp Stim Ykpn.

Wira, Variyetmi. 2012. "Pengaruh Kinerja Perusahaan Terhadap Likuiditas Saham Menggunakan Trading Turnover." Manajemen Dan Kewirausahaan 3: 97-120.

Yusra, Irdha, Rizka Hadya, and Nova Egawati. 2017. "Analisis Efektifitas Pengendalia Biaya, Perputaran Modal Kerja, Dan Rentabilitas Ekonomi Menggunakan Regresi Data Panel." 1(3): 153-66. 